\title{
Antianxiety medications for the treatment of complex agoraphobia: pharmacological interventions for a behavioral condition
}

This article was published in the following Dove Press journal:

Neuropsychiatric Disease and Treatment

18 October 2011

Number of times this article has been viewed

\section{Giampaolo Perna ${ }^{1-3}$ \\ Silvia Daccò ${ }^{2}$ \\ Roberta Menotti \\ Daniela Caldirola ${ }^{2}$}

'Department of Psychiatry and Neuropsychology, Faculty of Health, Medicine and Life Sciences, University of Maastricht, Maastricht, the Netherlands; ${ }^{2}$ Department of Clinical Neuroscience, San Benedetto Hospital, Hermanas Hospitalarias, Albese con Cassano, Como, Italy; ${ }^{3}$ Department of Psychiatry and Behavioral Sciences, Leonard M Miller School of Medicine, University of Miami, Miami, FL, USA
Correspondence: Giampaolo Perna Department of Clinical Neuroscience, San Benedetto Hospital, Hermanas Hospitalarias, via Roma 16, 22032 Albese con Cassano,

Como, Italy

Tel $+3903|429| 539$

Fax +3903I427246

Email pernagp@tin.it
Background: Although there are controversial issues (the "American view" and the "European view") regarding the construct and definition of agoraphobia (AG), this syndrome is well recognized and it is a burden in the lives of millions of people worldwide. To better clarify the role of drug therapy in AG, the authors summarized and discussed recent evidence on pharmacological treatments, based on clinical trials available from 2000, with the aim of highlighting pharmacotherapies that may improve this complex syndrome.

Methods: A systematic review of the literature regarding the pharmacological treatment of AG was carried out using MEDLINE, EBSCO, and Cochrane databases, with keywords individuated by MeSH research. Only randomized, placebo-controlled studies or comparative clinical trials were included.

Results: After selection, 25 studies were included. All the selected studies included patients with AG associated with panic disorder. Effective compounds included selective serotonin reuptake inhibitors, serotonin-norepinephrine reuptake inhibitors, tricyclic antidepressants, selective noradrenergic reuptake inhibitors, and benzodiazepines. Paroxetine, sertraline, citalopram, escitalopram, and clomipramine showed the most consistent results, while fluvoxamine, fluoxetine, and imipramine showed limited efficacy. Preliminary results suggested the potential efficacy of inositol; D-cycloserine showed mixed results for its ability to improve the outcome of exposure-based cognitive behavioral therapy. More studies with the latter compounds are needed before drawing definitive conclusions.

Conclusion: No studies have been specifically oriented toward evaluating the effect of drugs on AG; in the available studies, the improvement of AG might have been the consequence of the reduction of panic attacks. Before developing a "true" psychopharmacology of AG it is crucial to clarify its definition. There may be several potential mechanisms involved, including fearlearning processes, balance system dysfunction, high light sensitivity, and impaired visuospatial abilities, but further studies are warranted.

Keywords: panic, anxiety, avoidance, pharmacological treatment, drug therapy

\section{Introduction}

\section{Definition}

Agoraphobia (AG) is a phobic-anxious syndrome with a long history. The first account is credited to Westphal's classic 1871 description:

"The anxiety is at its most intense in enclosed spaces [...] (The patient) begins to feel hot, flustered, tremulous, foolish and panic stricken [...] some patients describe fear of developing a panic attack or exhibiting anxiety in the presence of others..."1 
Currently the two officially recognized diagnostic manuals used in psychiatric research are the Diagnostic and Statistical Manual for Mental Disorders, Fourth Edition, Text Revision (DSM-IV-TR) ${ }^{2}$ and the International Classification of Diseases, 10th revision (ICD-10). ${ }^{3}$ Each manual gives quite a different definition of AG, with only two common features that are clearly present:

- Marked distress in or avoidance of characteristic situations such as crowds, public places, and traveling alone and away from home;

- Experiencing symptoms of anxiety when confronted with the feared situation.

The most relevant differences in the diagnostic criteria are:

- $\mathrm{AG}$ is not recognized as an independent disorder in the DSM-IV-TR, while in the ICD-10 it is;

- There is an explicit reference to PAs or panic-like symptoms in the DSM-IV-TR, while in ICD-10 there is not (however, the latter requires at least two symptoms of a list fully overlapping with the one defined for PAs in the DSM-IV-TR);

- While the ICD-10 clarifies the excessive or unreasonable nature of AG, the DSM-IV-TR does not explicitly state this aspect;

- There are no explicit exclusion criteria for specific or social phobia in the ICD-10, whereas these are stated in the DSM-IV-TR.

Given these observations, it is not easy to find a widely accepted definition of AG; moreover, there is a current debate between those who strictly link AG with $\mathrm{PAs}^{4-6}$ and those who view $A G$ as an independent concept. ${ }^{7-9}$ The authors, well aware of this problem, and aware of the use of the DSM definition in all pharmacological studies referring to AG in some way, will discuss the topic of this review based on the DSM-IV-TR.

\section{AG as viewed in the United States and Europe}

Effective therapeutic and pharmacological strategies depend on the choice of a correct target; therefore, discussing current different views of the concept of AG may be relevant for the pharmacological discussion that will follow.

Psychiatrists in the United States, and many others worldwide, consider PAs as the organizing psychopathological phenomena of panic-agoraphobic disease. Unexpected PAs are the "primum movens" that induce a defensive reaction by patients with the development of anticipatory anxiety and AG., ${ }^{410}$ In this view, "true" AG is the direct consequence of PAs, although its severity depends on several aspecific individual factors (eg, temperament) that influence the adaptive reactions of an individual to PAs, as well as to any other threatening condition. On the other hand, many European psychiatrists embrace the idea that agoraphobic attitude precedes the development of PAs and panic disorder (PD); thus, a specific temperament is needed for the development of PD or for the development of AG without previous unexpected PAs. Studies on clinical population strongly support the "American view," while epidemiological studies on general population seem to support the "European view." The authors' impression is that, once again, the main problem is the lack of a clear definition of the concept, and it is probable that these two views refer to qualitatively different concepts. The critical point of difference may be related to the meaning of negative symptoms experienced in agoraphobic environments: the American view considers them as the expression of panic vulnerability, while the European view includes them as part of the physiological anxiety reaction. A detailed discussion of the concept of AG goes beyond the aim of this article, but for more information there are some excellent publications available. ${ }^{8,9,11}$

If the American view is accepted, pharmacological treatment of AG mainly relies on the blockade of PAs and on the facilitation of the extinction processes. If the European view is accepted, drug treatment of AG should focus on the modification of phobic temperament.

\section{Agoraphobic behaviors and medical illnesses}

Another open question is the classification and definition of patients with agoraphobic-like conditions who have concerns regarding incapacitation because of a medical condition, or fear of embarrassment because of unpredictable medical symptoms, but who fail to report panic-like symptoms.

Several medical conditions such as cardiovascular or respiratory diseases are associated with persistent worry about the occurrence of physical symptoms in different situations of daily life, resulting in anticipatory anxiety, which patients try to reduce by avoiding the feared situations or through seeking reassurance. ${ }^{12}$ In clinical practice, patients with heart failure or dyspnea crises are often afraid of staying in situations where help may not be available or where they have experienced clinical symptoms. This may in turn lead to heightened physiological arousal, to a more intense and generalized perception of physical signals, with catastrophic interpretations of harmless body sensations, 
resulting in anxiety symptoms and avoidant behaviors. Functional gastrointestinal disorders such as irritable bowel syndrome ${ }^{13}$ are associated with severe AG in patients with PD, but they may also induce avoidant behaviors without the co-occurrence of PD. Despite their potential clinical relevance, these agoraphobic-like conditions are often underestimated in clinical settings; the patients seek help mainly for physical symptoms, often not drawing attention to their phobic avoidance; and psychiatrists or psychologists rarely get to treat them. Consequently, research studies on these conditions - investigating potential pathogenetic mechanisms, relationships with other phobic syndromes, and treatment strategies - are lacking.

\section{Putative mechanisms underlying the development of agoraphobic behaviors} Fear conditioning and emotional learning in AG

Several studies have investigated the neurobiology of PAs, $\mathrm{PD}$, and $\mathrm{PD}$ with $\mathrm{AG}$, whereas $\mathrm{AG}$ either as a syndrome or as a distinct disorder has rarely been studied. Given the mentioned difficulties in defining AG, even data available using DSM criteria suggest that the pathophysiology of AG is not well understood and the brain areas associated with this condition have not yet been consistently identified. Moreover, no longitudinal studies are available in high-risk samples; thus, it is difficult to understand if abnormalities found are the consequence of the disorder or if they perhaps play an etiopathogenetic role.

Fear conditioning and emotional-learning processes are implicated in AG. Exposure to recurrent unexpected PAs may cause conditioning of fear to exteroceptive and interoceptive cues present during PAs, with the development of defensive behaviors leading to agoraphobic avoidance and anticipatory anxiety. Over time, via learning mechanisms of stimulus generalization, fear conditioning may extend to a range of stimuli resembling the original conditioned stimuli co-occurring with panic, worsening avoidance behaviors, and anxious anticipation of panic (the American view). Alternatively, agoraphobics may have a hypersensitive fearconditioning system that may facilitate triggering of PAs (the European view).

Unfortunately, all studies are based on the American view. Recent studies applying experimental conditioning paradigms found patients with $\mathrm{PD}$, compared with healthy controls, had an enhanced resistance to extinction learning of aversive conditioned responses,${ }^{14}$ a stronger proclivity toward fear-conditioned overgeneralization, ${ }^{15}$ and elevated fear responding to learned safety cues with slower acquisition in safety learning. ${ }^{16}$ Although these studies were not specifically focused on comparisons between patients with or without $A G$, their results support the idea that fear-learning processes and compromised capacity for inhibiting fear responses in safe contexts may be implicated in phobic avoidance in PD. ${ }^{17}$ Finally, a blunted fear-potentiated startle response to imagery of PA situations was observed in patients with $\mathrm{PD}$ and the most severe $\mathrm{AG}$, compared with patients without or with only moderate AG, suggesting a compromised underlying fear-defense brain circuitry in the condition of chronic hyperarousal related to broad conditioned avoidance and high anticipatory anxiety. ${ }^{18}$ It is not clear if these findings are the consequence of the disorder or if they precede it, since no longitudinal high-risk studies are available.

Neuroanatomical studies support the role of emotional learning processes in the development of fear responses. Indeed, this processes a highly complex mechanism that mainly involves the amygdala, with its projections to brain regions mediating the autonomic, endocrine, and behavioral components of the fear responses, and the ventromedial prefrontal cortex, exerting an inhibitory modulation on amygdala activation; however, it also implicates multiple interconnected neural pathways modulating attention, appraisal, safety/threat discrimination, and emotion regulation processes that interact with fear learning to influence the fear response. ${ }^{17,19-22}$

These pathways also seem to be involved in AG. In a recent single pilot functional magnetic resonance imaging study by Wittmann et al, ${ }^{20}$ researchers investigated neural mechanisms of AG and anticipatory anxiety in a small sample of patients with PD and AG using AG-specific stimuli (ie, pictures of agoraphobic situations). The study showed a significant activation in the parahippocampal cortex, the precuneus, and the insula during presentation of the AG-specific pictures, suggesting an involvement of higher spatial and visual processing, activation of autobiographical memory and self-referential aspects, and monitoring of internal physical sensations during induced agoraphobic anxiety; in addition, an increased activation of the amygdala and the inferior frontal cortex/insula in anxious anticipation of agoraphobic stimuli was found. Although this study is preliminary and control groups are missing, these findings support a potential connection between agoraphobic anxiety and the activations of several brain areas involved in perceptual and fear-learning processes.

Given the role of the mentioned brain structures in the modulation of agoraphobic behaviors, manipulating neurotransmitters' systems that are involved in their activation and de-activation could play a part in the treatment of AG. 
The serotonergic system may have an inhibitory action on the locus coeruleus and amygdala, it may reduce the hypothalamic release of corticotrophin-releasing factor, and it may inhibit one-way escape in the midbrain periaqueductal gray, ${ }^{23}$ thus modulating behavioral and physiological responses to fear or stressful stimuli. The noradrenergic system seems to modulate autonomic arousal and behavioral activation in response to threatening stimuli and stressful situations, while the release of dopamine in the prefrontal cortex and limbic regions may be involved in fear-conditioning processes and in the acquisition of conditioned fear behaviors in animal models. ${ }^{24}$ Consolidation of fear memory and fear extinction appear to be modulated by activity of the glutamatergic N-methyl-D-aspartate receptors (NMDARs) in the amygdala and limbic regions. ${ }^{21}$ Accordingly, antagonists of NMDARs impair fear acquisition and extinction if administered shortly before a conditioning session or after extinction training; ${ }^{25}$ the partial NMDAR agonist D-cycloserine (DCS), a novel compound that has been investigated in AG with $\mathrm{PD}$, may facilitate fear extinction during exposure therapy either by enhancing NMDAR function during extinction or by reducing NMDAR function during consolidation of fear memory. ${ }^{26}$ Finally, the gamma-aminobutyric acid (GABA) system may inhibit neuronal activation and excessive output within limbic structures and fear circuits, facilitating fear extinction. ${ }^{27}$

\section{Balance, visuospatial systems, and AG}

In the last years, several studies in patients with PD and AG found subclinical abnormalities of their balance system function that seem to influence the severity of AG and may contribute to their symptoms of dizziness and discomfort in complex sensorial environments (eg, shopping malls, traffic, crowds). ${ }^{28,29}$ The balance control of many patients with PD and AG appears to rely mainly on nonvestibular, proprioceptive, or mostly visual (visual dependence) cues; ${ }^{30}$ recent preliminary results from the authors' team showed a higher balance system reactivity to peripheral visual stimulation in patients with $\mathrm{PD}$ and $\mathrm{AG}$, possibly linked to a more active "visual alarm system", involving visual, vestibular, and limbic areas, that may influence the development of $A G$ in situations where environmental stimuli are uncertain. ${ }^{31}$ Overall, a "balance vulnerability" to AG may exist, and small postural modifications or sensorial stimuli from the surrounding environment may play a part in triggering situational anxiety/panic. Similarly, patients with phobic postural vertigo, a syndrome characterized by dizziness and autonomic/anxiety responses in standing or walking without specific vestibular diseases, often show AG-like behaviours, ${ }^{32}$ suggesting that high sensitivity to environmental conditions may also lead to phobic avoidance without PD.

Finally, patients with AG and PD showed visuospatial cognition biases, with scarce ability of spatial orientation and spatial navigation and visual memory deficits, possibly related to distortion of the representational mechanism of extrapersonal space; ${ }^{33}$ it has been proposed that an overprojection of the representation of the near space immediately surrounding the body (peripersonal space) has a role in claustrophobic fear. ${ }^{34}$

Patients with PD and AG also showed high sensitivity to environmental light or bright stimuli, having photophobic behavior, ${ }^{35}$ abnormal retinal light responses, and pupillary reflex dysfunctions, possibly linked to serotonergic and/or dopaminergic function. ${ }^{36}$ Moreover, since a relationship between photosensitivity and migraine exists, ${ }^{37}$ and a high comorbidity of PD with AG and migraine was found, ${ }^{38}$ a broader dysfunction of autonomic and/or serotonergic systems may link photosensitivity, migraine, PAs, and AG. ${ }^{39}$ Overall, the findings of high sensitivity of patients with $P D$ and AG to several stimuli in the surrounding environment support the idea that agoraphobic conditions may involve the activation of complex systems, beyond the simple fear of the recurrence of PAs, including emotional responses to destabilizing/unpleasant environmental situations and operant-learning processes related to the avoidance of physical experiences provoking discomfort in everyday life.

\section{Treatments for AG}

Until now, clinical studies, and consequently the current guidelines, have been focused on therapy for AG with PD, whereas studies on AG without PAs are lacking. Both pharmacological treatments with drugs acting on different neurotransmitters and cognitive behavioral therapy (CBT) may be effective in PD with AG. The debate is ongoing as to whether these treatments are equally effective and whether combined treatments provide additional benefits; recently, preliminary evidence has been reported of a better efficacy of combined therapy than antidepressants or psychotherapy alone in acute-phase treatment and some superiority of antidepressants as compared with CBT after 9 months of treatment. ${ }^{40}$ Overall, the main current guidelines state that at present it is not possible to ascertain which of these treatment modalities is more effective in $\mathrm{PD}$ with $\mathrm{AG}$, and specific criteria for choosing medication, CBT, or combined therapy are not available. ${ }^{41}$ The efficacy of CBT in AG with PD is 
thought to be explained by an activation and modification of relevant fear-learning processes via habituation and/or extinction and/or examining dysfunctional beliefs; however, $30 \%-40 \%$ of patients do not achieve significant improvement with CBT alone, ${ }^{42}$ making room for a potential utility of pharmacological interventions for this behavioral condition. Even though the mechanisms of action of the existing drugs with antipanic and antiphobic properties remain unclear, the utility of these drugs may be mediated by their effects on several brain pathways potentially involved in pathophysiology of AG with PD.

Medications acting on neurotransmitters appeared to obtain comparable rates of clinical remission for both PAs and agoraphobic avoidance in patients with $\mathrm{PD}$ and $\mathrm{AG}$, while the probability of relapses during long-term pharmacological treatment seems to be lower for AG than for PAs. ${ }^{43}$ Nevertheless, in a study by van Apeldoorn et al, ${ }^{44}$ between $20 \%$ and $40 \%$ of patients with PD and AG did not fully respond to adequate pharmacotherapy alone or, similarly, to CBT administered alone, and so far the combination of CBT and pharmacotherapy does not appear to fill this gap. In addition, $25 \%-50 \%$ of patients relapse within 6 months after drug discontinuation and up to $40 \%-50 \%$ of patients still have residual panic-phobic symptoms after 3-6 years. ${ }^{45}$ Finally, it is still unclear to what extent the pharmacological remission of both full and limited-symptom spontaneous PAs may indirectly influence the remission of $\mathrm{AG}$ in patients with $\mathrm{AG}$ and $\mathrm{PD}$, or to what extent a specific drug effect on phobic conditions is necessary to obtain a complete remission.

\section{Aim of the study}

Given the relevance of AG to the general population and the tendency of AG to become chronic, looking for effective treatments is important. To reach this goal, the authors will summarize and discuss recent evidence regarding the pharmacological treatment of AG, based on clinical trials available from 2000 to June 2011, discuss factors that might affect the validity of the studies, and, finally, suggest putative mechanisms that may be involved in the development of new drugs.

\section{Methods}

A scientific literature search was performed using MEDLINE, EBSCO, and Cochrane databases, with keywords individuated by MeSH research. These keywords included (AG OR "panic disorder") AND ("drug therapy" OR pharmacotherapy) AND behavior*; NOT (“depressive disorder” OR "mood disorder"); NOT ("psychotic disorder"). The syntax respected instruction information described in the databases. Citation searches were also conducted manually.

All studies were analyzed applying the following inclusion criteria:

- English-language articles

- Clinical trials

- Blinded studies

- Studies published after 2000

- Studies where psychopathological diagnosis was performed using DSM criteria, ICD-10 criteria, or an exact description of the disorder and duration of symptoms

- Clinical outcomes had to be scored by a standardized psychometric scale, by self-report, by observer-rated measures, by behavior test, or by a numeric rating index of anxiety and/or agoraphobic symptoms (eg, avoidance, anticipatory anxiety, and anxiety state)

- For the groups in the studies, each drug to be administrated without other drugs that can influence or interact with treatment.

For the selection of articles, exclusion criteria were:

- Trials not randomized controlled and without control group

- Case reports

- Studies where population's diagnosis was PD without AG

- Studies where AG was in comorbidity with other psychopathologies or neurological pathologies

- Studies with a pediatric population.

After selection, articles were divided on the basis of the pharmacological classes. After this subdivision, in each article the following parameters were identified and described: (1) characteristics of the studies; (2) drug therapies and doses; (3) duration of treatments; (4) control group(s); (5) outcome measures of agoraphobic symptoms and/or panic/anxiety; (6) timing of follow-up; and (7) results. When available, specific psychometric measures of AG were reported and highlighted; when these were lacking, global scores of psychometric scales that include evaluation of AG severity, such as the Panic and Agoraphobia Scale, the Panic Attack Symptoms Scale, or the Panic Disorder Severity Scale, were reported.

\section{Results}

The electronic search identified 235 articles. Among these, 210 were excluded and 25 studies were selected (Figure 1). No studies were found that focused on AG without PD, and all the selected studies included patients with AG and PD. Pharmacological classes used in the selected clinical trials are summarized in Table 1. Details of the selected studies are outlined in Table 2 . 


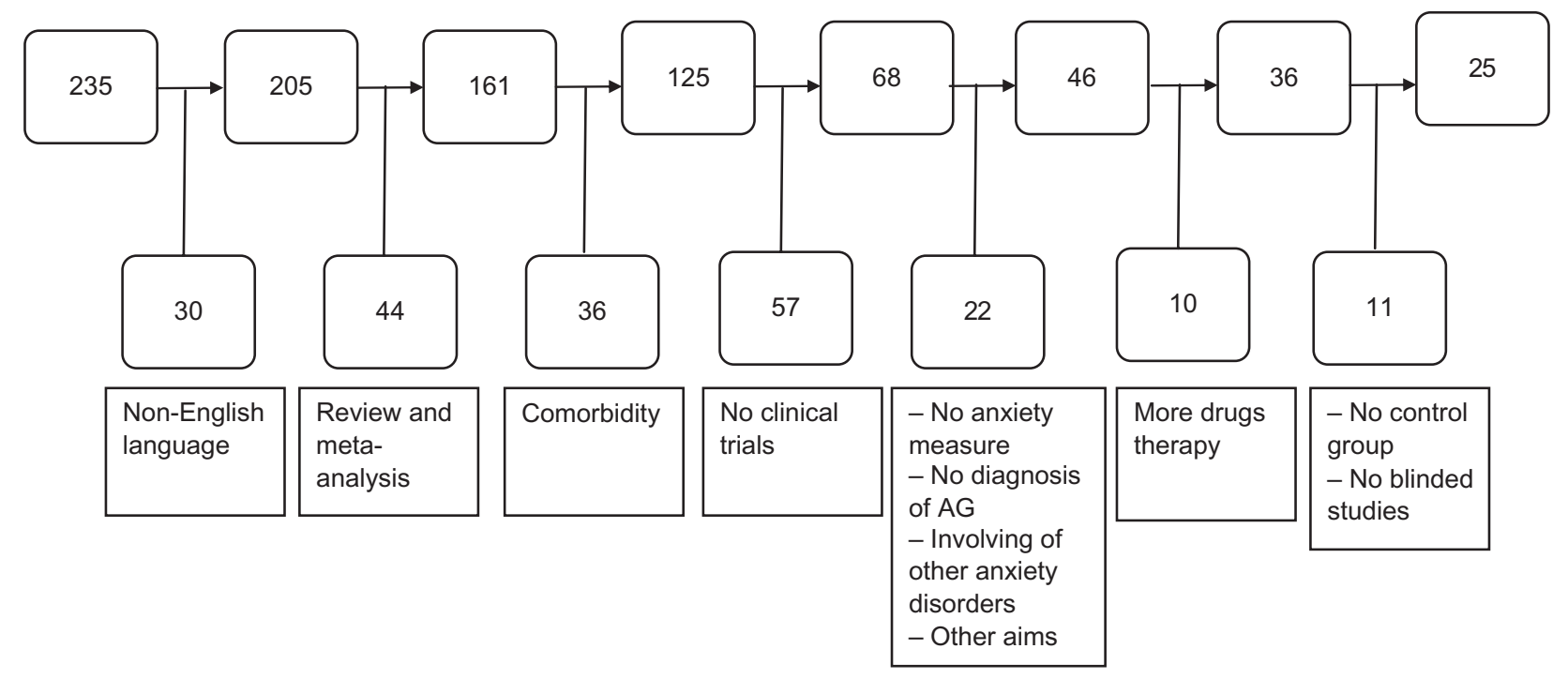

Figure I Selection of articles.

Abbreviation: AG, agoraphobia.

\section{Discussion}

This review of randomized, controlled pharmacological trials on AG published over the last 11 years underscores the difficulties in identifying psychotropic drugs that may specifically improve AG. Many reasons may explain these difficulties. Since the few studies that included patients with AG and panic-like symptoms (but without full-blown PD) had many methodological shortcomings (eg, lack of randomization or control groups), they were excluded from this review; therefore, no specific data on "not panic" agoraphobics are available. All the studies reported in this article included patients with AG associated with PD, as per DSM criteria, and so disentangling the specific effects of AG is difficult.

Table I Number of articles selected for each pharmacological class

\begin{tabular}{ll}
\hline Pharmacological class & Articles (n) \\
\hline TCAs & 5 \\
MAOls & $\mathrm{I}$ \\
BDZs & 3 \\
SSRIs & 8 \\
NARIs & 2 \\
SNRIs & $\mathrm{I}$ \\
Other & \\
$\quad$ Gabapentin (GABAergic anticonvulsant) & $\mathrm{I}$ \\
Inositol (natural isomer of glucose) & $\mathrm{I}$ \\
DCS (partial agonist of the NMDARs) & 2 \\
Pagoclone (partial agonist at the & $\mathrm{I}$ \\
GABA-A/BDZ receptor) & \\
\hline
\end{tabular}

Abbreviations: BDZ, benzodiazepine; DCS, D-cycloserine; GABA, gammaaminobutyric acid; MAOI, monoamine oxidase inhibitor; NARI, selective noradrenergic reuptake inhibitor; NMDAR, N-methyl-D-aspartate receptor; SNRI, serotoninnorepinephrine reuptake inhibitor; SSRI, selective serotonin reuptake inhibitor; TCA, tricyclic antidepressant.
The authors begin by discussing the putative limitations of the studies included. Many studies on PD with AG reported outcome measures evaluating only the global improvement of the clinical condition, without highlighting potential differences in drug effects on distinct clinical phenomena such as frequency of PAs, anticipatory anxiety, phobic avoidance, and their interaction. Moreover, some methodological issues may influence the results of the included studies. Several studies did not report effect size analysis in their results, thus decreasing the strength of their conclusions. The sample sizes were often small and some studies included patients with other psychiatric disorders in comorbidity with PD and $A G$, thus possibly affecting the external validity of the results and/or masking potential significant effects of the treatments. Some data arose from pharmaceutical studies that might have had different settings than spontaneous clinical studies, thus affecting the comparisons of the results. In a few comparative clinical trials, the placebo group was missing, ${ }^{48,52,57,60,62,63,68}$ even though the comparator drugs were well-known, effective antipanic drugs. Two studies ${ }^{60,62}$ were single-blinded (eg, the investigator rating psychometric scales did not know which treatment was administered, whereas the patients did), thus patients' expectance of treatment efficacy cannot be excluded as an influence. Finally, all studies but two ${ }^{44,45}$ considered short-term outcomes, not allowing for conclusions regarding maintenance properties and long-term effects of the tested drugs.

Keeping these limitations in mind, the authors found that selective serotonin reuptake inhibitors (SSRIs) and tricyclic antidepressants (TCAs) are the most studied drugs in AG 
with $\mathrm{PD}$, according to previous reviews. ${ }^{12,23}$ Among SSRIs, paroxetine is the most used drug in the selected clinical trials, ${ }^{48,54-57,60,62,63}$ showing high efficacy on both panic and phobic symptoms, and also when severity of AG is measured by specific psychometric scales. The comparison between CBT and paroxetine suggests their similar efficacy on agoraphobic behaviors but with some superiority of paroxetine on PAs in the acute phases of the treatment; ${ }^{55}$ finally, the addition of paroxetine to $\mathrm{CBT}$ in patients that did not respond to CBT alone is significantly more effective in improving agoraphobic behaviors than the addition of placebo. ${ }^{54}$

Overall these data indicate the utility of paroxetine as a pharmacological augmentation strategy in patients with AG who do not fully respond to CBT sessions and they underscore its efficacy on PAs. Since the recurrence of PAs worsen agoraphobic behaviors in $\mathrm{PD}$ and interfere with the remission of AG, the efficacy of paroxetine on AG may also be linked to its antipanic properties; thus, treatment with paroxetine in patients with $A G$ and a high recurrence of PAs may be more appropriate than CBT alone. Sertraline, ${ }^{48,57}$ citalopram, ${ }^{58-60}$ and escitalopram ${ }^{58,59}$ also appear to be effective in PD with AG, whereas fluvoxamine ${ }^{48,68}$ shows less consistent efficacy, at least on PAs and global panic-phobic psychometric measures. Although showing a suppressive effect on spontaneous PAs, fluoxetine ${ }^{53}$ does not appear to be effective on situational PAs compared with placebo, and its efficacy on AG measures is limited; these findings are similar to those in a study on imipramine performed before $2000,{ }^{71}$ supporting the idea that antidepressants may not have a similar effect on all aspects of PD with AG. Among TCAs, which are less tolerable and safe than SSRIs, clomipramine shows an efficacy on both panic and phobic symptoms similar to paroxetine and sertraline, ${ }^{48}$ whereas imipramine shows mixed results; indeed, although imipramine is more effective than placebo in long-term maintenance, ${ }^{44}$ it appears to be less effective than sertraline on short-term outcomes, ${ }^{48}$ as measured by global panic-phobic psychometric scales, and a combined therapy with CBT plus imipramine does not offer significant benefits on agoraphobic symptoms compared with CBT plus placebo. ${ }^{46}$

Benzodiazepines (BDZs), such as clonazepam ${ }^{50,51}$ and alprazolam ${ }^{52}$ are effective in AG with PD and the association of alprazolam to antidepressant in the first weeks of therapy may accelerate the reduction of global anxiety, ${ }^{52}$ whereas the only study on pagoclone,${ }^{64}$ a partial agonist of GABA-A $\mathrm{BDZ}$ receptors, shows inconsistent results. However, the use of BDZs is recommended with caution, because of risk of tolerance, dependence, and withdrawal symptoms $;{ }^{70}$ moreover, patients receiving combined therapy with $\mathrm{CBT}$ and $\mathrm{BDZs}$ who subsequently discontinue BDZ treatment experience a loss of efficacy compared with CBT and placebo, possibly due to interference of BDZs with fear-extinction processes. ${ }^{70}$

Among other pharmacological classes, venlafaxine ${ }^{63}$ appears to be effective on both panic and phobic symptoms; the only study with inositol ${ }^{68}$ supports the effectiveness in AG with PD emerging from previous clinical trials, ${ }^{71,72}$ but more studies are needed before drawing definitive conclusions. Reboxetine ${ }^{61}$ appears to be effective on both panic and phobic symptoms compared with placebo, while when compared with paroxetine ${ }^{62}$ it shows a similar efficacy on phobic avoidance and anticipatory anxiety but a lower efficacy on PAs; these data support the role of the noradrenergic system in modulation of avoidance behaviors but underscore the relevance of acting on the serotonergic system to decrease the PAs. Finally, gabapentin ${ }^{64}$ does not show different efficacy than placebo and moclobemide ${ }^{49}$ does not decrease phobic avoidance compared with placebo, even though it does show some efficacy on PAs.

As previously discussed, despite these pharmacological therapeutic options available for PD with AG, they do not seem to be able to achieve a full remission in all treated patients either when administered alone or in association with CBT ${ }^{67}$ Beyond the discussed absence of a widely accepted definition, this critical issue may be partly related to the pathogenetic complexity of $A G$, which is not usually taken into account in clinical trials. A preliminary open study showed that citalopram influences the balance system in patients with $\mathrm{PD}$ and $\mathrm{AG}$ by improving their postural stability, as measured by static posturography, especially when visual information is lacking; in addition, patients whose posturography scores were highly abnormal at the end of the trial were still agoraphobic, whereas most patients whose balance system function improved were no longer agoraphobic, underscoring the involvement of balance system dysfunction in PD with AG and the relevance of the serotonergic system in connections between balance and AG. ${ }^{73}$ Further studies are warranted to investigate the possible role of unrecognized balance dysfunctions in patients with $\mathrm{PD}$ and $\mathrm{AG}$ who do not fully respond to treatments and to study appropriate interventions.

A reanalysis of pooled samples of patients from previous homogeneous pharmacological studies performed by the authors' team showed a higher efficacy of sertraline and clomipramine than paroxetine, fluvoxamine, and citalopram on agoraphobic symptoms (unpublished data). This finding may be related to their additional ability to modulate the dopaminergic system, besides their main effect on 
Table 2 Systematic analysis of selected studies

\begin{tabular}{|c|c|c|c|c|}
\hline $\begin{array}{l}\text { Pharmacological } \\
\text { class }\end{array}$ & Reference & Study characteristics & $\begin{array}{l}\text { Drug therapy (dosage) } \\
\text { in experimental group }\end{array}$ & $\begin{array}{l}\text { Duration of treatment } \\
\text { administration }\end{array}$ \\
\hline TCAs & $\begin{array}{l}\text { Mavissakalian } \\
\text { and Perel }\end{array}$ & $\begin{array}{l}\text { Double-blind, crossover design } \\
\text { Aim: to test the effects of } \\
\text { imipramine maintenance } \\
\text { therapy in a second-year } \\
\text { extension of a previous study }\end{array}$ & $\begin{array}{l}\text { Imipramine } \\
(2.25 \mathrm{mg} / \mathrm{kg} / \text { day })\end{array}$ & $\begin{array}{l}\text { Maintenance of imipramine } \\
\text { therapy ( } 1 \text { year) in patients } \\
\text { who had taken imipramine for } \\
\text { a year before this study, after } \\
\text { stable remission obtained by } \\
\text { 6-month imipramine acute-phase } \\
\text { treatment }\end{array}$ \\
\hline
\end{tabular}

Mavissakalian and Perel ${ }^{46}$

Marchand

et $\mathrm{al}^{47}$

Bandelow

et $\mathrm{al}^{48}$

Perna et $\mathrm{al}^{49}$

Double-blind, randomized, controlled trial

Multicenter, double-blind, randomized, placebocontrolled trial
Uhlenhuth et a $\left.\right|^{50}$ previous studies

Aim: to explore relationship

between duration of

imipramine therapy and relapse

Double-blind, randomized,

placebo-controlled trial

Double-blind, randomized, placebo-controlled trial

Clomipramine

(max II $2.5 \mathrm{mg} /$ day)
Imipramine

$(2.25 \mathrm{mg} / \mathrm{kg} /$ day $)$

6 months of imipramine therapy

Imipramine (25-200 mg/day) + CBT groups (cognitive and exposure or cognitive or exposure or supportive therapy)

22 weeks, including 4 weeks before beginning of CBT and 18 weeks during $\mathrm{CBT}$

MAOIs

Clomipramine

(max $50 \mathrm{mg} /$ day)

Moclobemide (75, 150, 300, 600 , or $900 \mathrm{mg} /$ day)
10 weeks

30 days

8 weeks 


\begin{tabular}{l} 
Control group(s) \\
\hline I. Maintenance of placebo condition \\
(I year) in patients who had taken \\
placebo for a year before this study, \\
after stable remission obtained by \\
6-month imipramine acute-phase \\
treatment \\
2. Placebo substitution (I year) in \\
patients who had taken imipramine \\
for a year before this study, after \\
stable remission obtained by 6-month \\
imipramine acute-phase treatment \\
I2-I4, I8, or 30 months \\
of imipramine therapy
\end{tabular}

Placebo + CBT treatment groups (cognitive and exposure or cognitive or exposure or supportive therapy)

\section{Outcome measures for AG and/or panic/anxiety \\ AG subscale of $\mathrm{FQ}$ \\ Individualized clinical measure \\ of phobic anxiety and avoidance (9-point scale) \\ Functional in vivo measure \\ of phobic anxiety derived from \\ a behavioral assessment \\ (9-point scale) \\ Number and severity of PAs}

\section{AG subscale of $\mathrm{FQ}$}

Individualized clinical measure

of phobic anxiety and avoidance

(9-point scale)

Functional in vivo measure

of phobic anxiety derived from

a behavioral assessment

(9-point scale)

Number and severity of PAs

ACQ

MI-A

MI-PF
P\&A total scores and subscales, including avoidance and anticipatory anxiety subscales BAI FQ
ND

Week 22

$3,6,12$

months post

treatment

ND

30 days

FQ

Agoraphobic avoidance and anticipatory anxiety - CGI

II-point scale of fear and 5-point scale of avoidance for main phobic situations or activities Unexpected and situational PAs (daily diary)

\section{Results}

Significant effect of imipramine in maintenance remission
No difference in relapse rate in the different groups

Patients who relapsed showed lower severity of agoraphobic symptoms than pretreatment phase, whereas number of PAs measured at relapse and pretreatment phase did not differ

At week 22, anxiety and agoraphobic symptoms significantly decreased in imipramine and placebo groups without differences between groups; after 12 months no significant differences were detected within and between groups In imipramine group, the proportion of panic-free patients post treatment and at 12 months did not differ among CBT treatments; in placebo group these data were not shown

Both exercise and clomipramine led to a significant global improvement in comparison with placebo

Overall, clomipramine was significantly more effective and faster in improving anxiety, panic, and phobic symptoms than exercise; however, exercise exerted its effect mainly reducing anticipatory anxiety and panicrelated disability and the decrease of $\mathrm{FQ}$ scores in exercise group was higher than placebo group and similar to clomipramine group FQ scores decreased significantly in all treatment groups

PASS scores decreased significantly in all but the fluvoxamine treatment group Sertraline was more effective than imipramine in improving PASS scores

Weeks I, 2, 3, Moclobemide significantly improved both $4,6,8 \quad$ unexpected and situational PAs (systematic dose-related effect), whereas it did not show significant difference to placebo in fear and phobic avoidance 
Table 2 (Continued)

\begin{tabular}{|c|c|c|c|c|}
\hline $\begin{array}{l}\text { Pharmacological } \\
\text { class }\end{array}$ & Reference & Study characteristics & $\begin{array}{l}\text { Drug therapy (dosage) } \\
\text { in experimental group }\end{array}$ & $\begin{array}{l}\text { Duration of treatment } \\
\text { administration }\end{array}$ \\
\hline \multirow[t]{3}{*}{ BDZs } & $\begin{array}{l}\text { Valença } \\
\text { et } \mathrm{al}^{51}\end{array}$ & $\begin{array}{l}\text { Double-blind, randomized, } \\
\text { placebo-controlled trial }\end{array}$ & Clonazepam (2 mg/day) & 6 weeks \\
\hline & $\begin{array}{l}\text { Valença } \\
\text { et } \mathrm{al}^{52}\end{array}$ & $\begin{array}{l}\text { Randomized, placebo- } \\
\text { controlled trial }\end{array}$ & Clonazepam (2 mg/day) & 6 weeks \\
\hline & $\begin{array}{l}\text { Katzelnick } \\
\text { et } \mathrm{al}^{53}\end{array}$ & $\begin{array}{l}\text { Multicenter, naturalistic, } \\
\text { randomized study }\end{array}$ & $\begin{array}{l}\text { Alprazolam } \\
(0.25 \text { to }>5 \mathrm{mg} / \text { day })+ \\
\text { SSRIs/SNRIs }\end{array}$ & $\begin{array}{l}8 \text { weeks (including 3- to 4-week } \\
\text { taper of alprazolam) }\end{array}$ \\
\hline \multirow[t]{5}{*}{ SSRIs } & $\begin{array}{l}\text { Uhlenhuth } \\
\text { et al }{ }^{54}\end{array}$ & $\begin{array}{l}\text { Multicenter, double-blind, } \\
\text { randomized, placebo- } \\
\text { controlled trial }\end{array}$ & $\begin{array}{l}\text { Fluoxetine (one group } \\
10 \mathrm{mg} / \text { day; one group } \\
20 \mathrm{mg} / \text { day) }\end{array}$ & 10 weeks \\
\hline & $\begin{array}{l}\text { Kampman } \\
\text { et al }{ }^{55}\end{array}$ & $\begin{array}{l}\text { Double-blind, randomized, } \\
\text { placebo-controlled trial } \\
\text { Patients unsuccessfully treated } \\
\text { with initial manual-guided CBT } \\
\text { alone (I5 sessions) }\end{array}$ & $\begin{array}{l}\text { Paroxetine (to } 40 \mathrm{mg} / \mathrm{day} \text { ) + } \\
\text { CBT }\end{array}$ & 8 weeks \\
\hline & $\begin{array}{l}\text { Hendriks } \\
\text { et } \mathrm{al}^{56}\end{array}$ & $\begin{array}{l}\text { Randomized, controlled trial } \\
\text { Patients aged } 60 \text { years and } \\
\text { older }\end{array}$ & Paroxetine (to $40 \mathrm{mg} /$ day) & 26 weeks \\
\hline & $\begin{array}{l}\text { Wedekind } \\
\text { et al }{ }^{57}\end{array}$ & $\begin{array}{l}\text { Double-blind, randomized, } \\
\text { placebo-controlled trial }\end{array}$ & $\begin{array}{l}\text { Paroxetine }(10-40 \mathrm{mg} / \text { day })+ \\
\text { relaxation training or aerobic } \\
\text { exercise }\end{array}$ & 10 weeks \\
\hline & $\begin{array}{l}\text { Bandelow } \\
\text { et a }\left.\right|^{58}\end{array}$ & $\begin{array}{l}\text { Double-blind, randomized, } \\
\text { controlled trial }\end{array}$ & Sertraline (50-150 mg/day) & 12 weeks \\
\hline
\end{tabular}




\begin{tabular}{|c|c|c|c|}
\hline Control group(s) & $\begin{array}{l}\text { Outcome measures for AG } \\
\text { and/or panic/anxiety }\end{array}$ & $\begin{array}{l}\text { Timing of } \\
\text { follow-up }\end{array}$ & Results \\
\hline Placebo & $\begin{array}{l}\text { PASS } \\
\text { HAM-A } \\
\text { CGI }\end{array}$ & Week 6 & $\begin{array}{l}\text { Clonazepam showed significant reduction of } \\
\text { anticipatory anxiety, phobic avoidance, PAs, } \\
\text { global anxiety, and CGI scores compared } \\
\text { with placebo }\end{array}$ \\
\hline Placebo & $\begin{array}{l}\text { GPI for PD } \\
\text { Number of PAs } \\
\text { HAM-A }\end{array}$ & Weeks 2, 6 & $\begin{array}{l}\text { In clonazepam group, by end of week } 6 \text { there } \\
\text { was a statistically significant remission of PAs } \\
\text { and decrease in anxiety }\end{array}$ \\
\hline SSRIs/SNRIs alone & $\begin{array}{l}\text { Number of PAs } \\
\text { HAM-A } \\
\text { GPI } \\
\text { CGI-I }\end{array}$ & $\begin{array}{l}\text { Weeks I, 2, 3, } \\
4,5,6,7,8\end{array}$ & $\begin{array}{l}\text { Combined therapy showed an earlier onset } \\
\text { of effect on anxiety and global improvement } \\
\text { measures than SSRIs/SNRIs alone } \\
\text { PAs decreased significantly at week } 8 \text { in } \\
\text { both groups without differences between } \\
\text { treatment groups at any time point }\end{array}$ \\
\hline Placebo & $\begin{array}{l}\text { Index of AG (0- to 8-point scale) } \\
\text { Number of spontaneous and } \\
\text { situational PAs (daily diary) }\end{array}$ & $\begin{array}{l}\text { Weeks I, 2, 4, } \\
6,8,10\end{array}$ & $\begin{array}{l}\text { Fluoxetine showed a statistically significant, } \\
\text { dose-dependent suppressive effect on } \\
\text { spontaneous PAs, whereas there were no } \\
\text { significant drug effects on situational PAs } \\
\text { A therapeutic effect of fluoxetine on AG was } \\
\text { found only at the lower dose }\end{array}$ \\
\hline Placebo + CBT & $\begin{array}{l}\text { ACQ } \\
\text { MI-A (total score, MI-A and } \\
\text { MI-PF subscales) } \\
\text { ADS }\end{array}$ & Week 8 & $\begin{array}{l}\text { Patients in paroxetine }+ \text { CBT condition } \\
\text { significantly improved on agoraphobic } \\
\text { behaviors and anxiety discomfort } \\
\text { Trend showed more panic-free patients in } \\
\text { CBT + paroxetine group }\end{array}$ \\
\hline $\begin{array}{l}\text { I. CBT } \\
\text { 2. I4-week WL }\end{array}$ & $\begin{array}{l}\text { ACQ } \\
\text { MI-A } \\
\text { Proportion of patients free } \\
\text { from PAs (panic-free ratio) }\end{array}$ & $\begin{array}{l}\text { Weeks } 8,14 \\
\text { (conclusion } \\
\text { CBT/WL), } \\
26 \text { (treated } \\
\text { patients only) }\end{array}$ & $\begin{array}{l}\text { Compared with the WL, the 8- and I4-week } \\
\text { ACQ and MI-A scores had significantly } \\
\text { improved for both the paroxetine and the } \\
\text { CBT conditions; the improvements were } \\
\text { sustained at the } 26 \text {-week follow-up without } \\
\text { differences between groups } \\
\text { The baseline-to- } 14 \text { weeks panic-free ratio } \\
\text { in the paroxetine condition had increased } \\
\text { significantly, an improvement that was } \\
\text { sustained at week } 26 \\
\text { Although not statistically significant, in the } \\
\text { CBT condition, the baseline-to- } 14 \text { weeks } \\
\text { ratio had risen and had improved further at } \\
\text { follow-up (statistical trend) } \\
\text { The panic-free ratio for the WL showed no } \\
\text { changes over time }\end{array}$ \\
\hline $\begin{array}{l}\text { Placebo }+ \text { relaxation training } \\
\text { or aerobic exercise }\end{array}$ & $\begin{array}{l}\text { P\&A } \\
\text { HAM-A } \\
\text { BAI } \\
\text { CGI }\end{array}$ & $\begin{array}{l}\text { Weeks I, 2, 4, } \\
6,8,10\end{array}$ & $\begin{array}{l}\text { P\&A, CGI, and BAI scores decreased } \\
\text { significantly in all treatment groups over } \\
\text { time, but paroxetine-treated patients were } \\
\text { significantly more improved than placebo- } \\
\text { treated patients } \\
\text { On the CGI, patients in the exercise groups } \\
\text { (+ paroxetine or placebo) had a trend } \\
\text { toward better improvement compared with } \\
\text { relaxation } \\
\text { HAM-A scores decreased significantly, } \\
\text { without differences, in all treatment groups }\end{array}$ \\
\hline Paroxetine $(40-60 \mathrm{mg} /$ day $)$ & $\begin{array}{l}\text { P\&A } \\
\text { Frequency and intensity of PAs } \\
\text { and anticipatory anxiety } \\
\text { (panic diary) }\end{array}$ & $\begin{array}{l}\text { Weeks I, 2, 4, } \\
6,8,12\end{array}$ & $\begin{array}{l}\text { Sertraline and paroxetine showed equivalent } \\
\text { efficacy } \\
\text { Sertraline was significantly better tolerated } \\
\text { and was associated with significantly less } \\
\text { clinical worsening during taper than paroxetine }\end{array}$ \\
\hline
\end{tabular}


Table 2 (Continued)

\begin{tabular}{|c|c|c|c|c|}
\hline $\begin{array}{l}\text { Pharmacological } \\
\text { class }\end{array}$ & Reference & Study characteristics & $\begin{array}{l}\text { Drug therapy (dosage) } \\
\text { in experimental group }\end{array}$ & $\begin{array}{l}\text { Duration of treatment } \\
\text { administration }\end{array}$ \\
\hline & Stahl et a ${ }^{59}$ & $\begin{array}{l}\text { Multicenter, double-blind, } \\
\text { randomized, placebo- } \\
\text { controlled trial }\end{array}$ & $\begin{array}{l}\text { Escitalopram }(5 \mathrm{mg} / \text { day } \div \max \\
20 \mathrm{mg} / \text { day }) \\
\text { Citalopram }(10 \mathrm{mg} / \text { day } \div \max \\
40 \mathrm{mg} / \text { day })\end{array}$ & 10 weeks \\
\hline & $\begin{array}{l}\text { Bandelow } \\
\text { et } \mathrm{al}^{60}\end{array}$ & $\begin{array}{l}\text { Double-blind, randomized, } \\
\text { placebo-controlled trial }\end{array}$ & $\begin{array}{l}\text { Escitalopram }(5 \mathrm{mg} / \text { day } \div \max \\
20 \mathrm{mg} / \text { day }) \\
\text { Citalopram }(10 \mathrm{mg} / \text { day } \div \max \\
40 \mathrm{mg} / \text { day })\end{array}$ & 10 weeks \\
\hline & Perna et $a^{\mid 61}$ & $\begin{array}{l}\text { Single-blind, randomized, } \\
\text { controlled trial }\end{array}$ & $\begin{array}{l}\text { Citalopram (10 mg/day } \div \max \\
50 \mathrm{mg} / \text { day })\end{array}$ & ND \\
\hline \multirow[t]{2}{*}{ NARIs } & $\begin{array}{l}\text { Versiani } \\
\text { et al }{ }^{62}\end{array}$ & $\begin{array}{l}\text { Double-blind, randomized, } \\
\text { placebo-controlled trial }\end{array}$ & Reboxetine (2-8 mg/day) & 8 weeks \\
\hline & $\begin{array}{l}\text { Bertani } \\
\text { et } \mathrm{al}^{63}\end{array}$ & $\begin{array}{l}\text { Single-blind, randomized, } \\
\text { controlled trial }\end{array}$ & Reboxetine (2-8 mg/day) & 90 days \\
\hline SNRIs & Pollack et a ${ }^{64}$ & $\begin{array}{l}\text { Double-blind, randomized, } \\
\text { controlled trial }\end{array}$ & $\begin{array}{l}\text { Venlafaxine extended release } \\
\text { ( } 75 \text { or } 150 \mathrm{mg} / \text { day) }\end{array}$ & 12 weeks \\
\hline \multirow[t]{4}{*}{ Other } & Pande et $\mathrm{a}^{65}$ & $\begin{array}{l}\text { Double-blind, randomized, } \\
\text { placebo-controlled trial }\end{array}$ & Gabapentin (600-3600 mg/day) & 8 weeks \\
\hline & $\begin{array}{l}\text { Sandford } \\
\text { et } \mathrm{al}^{66}\end{array}$ & $\begin{array}{l}\text { Double-blind, randomized, } \\
\text { placebo-controlled, crossover } \\
\text { design }\end{array}$ & Pagoclone (0.3 mg/day) & 2 weeks \\
\hline & Otto et $\mathrm{a}^{67}$ & $\begin{array}{l}\text { Randomized, double- } \\
\text { blind, placebo-controlled } \\
\text { augmentation trial }\end{array}$ & $\begin{array}{l}\mathrm{DCS}(50 \mathrm{mg})+\mathrm{CBT} \\
\text { (five sessions) }\end{array}$ & $\begin{array}{l}\text { Administration I hour } \\
\text { before CBT sessions 3-5 }\end{array}$ \\
\hline & $\begin{array}{l}\text { Siegmund } \\
\text { et } \mathrm{al}^{68}\end{array}$ & $\begin{array}{l}\text { Double-blind, randomized, } \\
\text { placebo-controlled trial }\end{array}$ & $\mathrm{DCS}(50 \mathrm{mg})+\mathrm{CBT}$ & $\begin{array}{l}\text { Administration once before CBT } \\
\text { exposure sessions (only weeks } \\
2,3,4 \text { ) }\end{array}$ \\
\hline
\end{tabular}




\begin{tabular}{|c|c|c|c|}
\hline Control group(s) & $\begin{array}{l}\text { Outcome measures for AG } \\
\text { and/or panic/anxiety }\end{array}$ & $\begin{array}{l}\text { Timing of } \\
\text { follow-up }\end{array}$ & Results \\
\hline Placebo & $\begin{array}{l}\text { P\&A } \\
\text { Anticipatory anxiety and number } \\
\text { of PAs (from PASS score) } \\
\text { CGI-phobic avoidance } \\
\text { HAM-A }\end{array}$ & $\begin{array}{l}\text { Weeks I, 2, 4, } \\
6,8,10\end{array}$ & $\begin{array}{l}\text { At the endpoint, escitalopram (vs placebo) } \\
\text { had significant effect on anticipatory anxiety } \\
\text { and HAM-A scores } \\
\text { Both escitalopram and citalopram had } \\
\text { significant effect on number of PAs and } \\
\text { CGI-phobic avoidance score compared } \\
\text { with placebo, without significant differences } \\
\text { between them }\end{array}$ \\
\hline Placebo & $\begin{array}{l}\text { P\&A (agoraphobic avoidance } \\
\text { behavior, anticipatory anxiety } \\
\text { and PAs subscales) }\end{array}$ & Week 10 & $\begin{array}{l}\text { Compared with placebo, escitalopram had } \\
\text { significant effect on agoraphobic avoidance } \\
\text { behavior and anticipatory anxiety subscales } \\
\text { and citalopram on anticipatory anxiety } \\
\text { subscale } \\
\text { Both drugs, compared with placebo, } \\
\text { significantly decreased the number of PAs, } \\
\text { without differences between them }\end{array}$ \\
\hline Paroxetine $(10 \mathrm{mg} /$ day $\div \max$ & PASS & Days 7, 60 & Both drugs significantly improved panic and \\
\hline 50 mg/day) & $\mathrm{FQ}$ & & $\begin{array}{l}\text { phobic symptomatology } \\
\text { A trend of higher efficacy of paroxetine in } \\
\text { reducing PAs was found }\end{array}$ \\
\hline Placebo & SPAAS and number of PAs & $\begin{array}{l}\text { Weeks I, 2, 3, } \\
4,5,6,7,8\end{array}$ & $\begin{array}{l}\text { At last assessment, anticipatory anxiety, AG, } \\
\text { and PAs significantly decreased in reboxetine } \\
\text { group }\end{array}$ \\
\hline Paroxetine (10 mg/day $\div 40 \mathrm{mg} /$ day $)$ & $\begin{array}{l}\text { PASS } \\
\text { FQ }\end{array}$ & Day 90 & $\begin{array}{l}\text { A greater effect of paroxetine than } \\
\text { reboxetine on PAs was found, while no } \\
\text { differences for anticipatory anxiety and } \\
\text { phobic avoidance were found }\end{array}$ \\
\hline $\begin{array}{l}\text { I. Placebo } \\
\text { 2. Paroxetine ( } 40 \mathrm{mg} / \mathrm{day})\end{array}$ & $\begin{array}{l}\text { PAAS (anticipatory anxiety } \\
\text { and PAs subscales) } \\
\text { Phobic fear and avoidance } \\
\text { of phobia scale } \\
\text { HAM-A } \\
\text { PDSS }\end{array}$ & $\begin{array}{l}\text { Weeks I, 2, 3, } \\
4,6,8,10,12\end{array}$ & $\begin{array}{l}\text { Venlafaxine and paroxetine showed } \\
\text { significant effects on all measures, compared } \\
\text { with placebo, without differences between } \\
\text { them }\end{array}$ \\
\hline Placebo & $\begin{array}{l}\text { P\&A total score } \\
\text { HAM-A }\end{array}$ & Week 8 & $\begin{array}{l}\text { No significant reduction of anxiety and panic } \\
\text { symptoms in gabapentin group compared } \\
\text { with placebo } \\
\text { A trend of higher efficacy in a subgroup of } \\
\text { more severely ill patients was found }\end{array}$ \\
\hline Placebo & $\begin{array}{l}\text { HAM-A } \\
\text { Frequency of PAs (diary) }\end{array}$ & $\begin{array}{l}\text { Weeks I, 2, 3, } \\
4,5,6\end{array}$ & $\begin{array}{l}\text { Statistical trend of decrease in the number of } \\
\text { PAs within pagoclone group was found, but } \\
\text { no differences were found when compared } \\
\text { with placebo }\end{array}$ \\
\hline Placebo (50 mg) + CBT (five sessions) & $\begin{array}{l}\text { PDSS } \\
\text { CGI-S for PD (global score, } \\
\text { number and frequency of PAs, } \\
\text { anticipatory anxiety, phobic } \\
\text { avoidance, impairment of function) }\end{array}$ & $\begin{array}{l}\text { I week (post } \\
\text { treatment) } \\
\text { and I month } \\
\text { (follow-up) } \\
\text { following } \\
\text { cessation of } \\
\text { treatment }\end{array}$ & $\begin{array}{l}\text { DCS had an augmentation effect on CBT } \\
\text { efficacy } \\
\text { PDSS and CGI-S decreased significantly in } \\
\text { DCS group (vs placebo) post treatment, } \\
\text { whereas no significant differences between } \\
\text { groups were shown in follow-up }\end{array}$ \\
\hline Placebo + CBT & $\begin{array}{l}\text { P\&A } \\
\text { BAI } \\
\text { HAM-A }\end{array}$ & $\begin{array}{l}\text { After II CBT } \\
\text { sessions and } \\
\text { at I and } 5 \\
\text { months after } \\
\text { end of CBT }\end{array}$ & $\begin{array}{l}\text { Both groups profited considerably from } \\
\text { therapy and DCS did not significantly } \\
\text { improve the outcome } \\
\text { There was a statistical trend in the more } \\
\text { severely ill patients that DCS accelerated } \\
\text { symptom reduction post therapy }\end{array}$ \\
\hline
\end{tabular}


Table 2 (Continued)

\begin{tabular}{llll}
\hline $\begin{array}{l}\text { Pharmacological } \\
\text { class }\end{array}$ & Reference & Study characteristics & $\begin{array}{l}\text { Drug therapy (dosage) } \\
\text { in experimental group }\end{array}$ \\
\hline & Palatnik $^{69}$ & $\begin{array}{l}\text { Double-blind, randomized, } \\
\text { controlled, crossover design }\end{array}$ & Inositol (I8 g/day) \\
& &
\end{tabular}

the serotonergic system, thus potentially influencing several mechanisms involved in shaping agoraphobic behaviors, such as balance, ${ }^{33}$ light stimuli sensitivity, ${ }^{35}$ and conditioning processes $;{ }^{24}$ however, this idea remains speculative and should be tested in further studies.

Besides well-known antianxiety medications, new emerging drugs are being tested in AG with PD, with the main aim of enhancing the retention of therapeutic learning and fear extinction provided by exposure-based CBT. DCS has improved outcomes from exposure therapy in a virtual reality environment in height-phobic patients. ${ }^{75}$ DCS has shown mixed results in patients with $\mathrm{PD}$ and $\mathrm{AG}$; in a recent study DCS appears to accelerate symptom reduction in more severely ill patients but fails to improve the outcome of CBT in the whole sample of patients with PD and AG. ${ }^{67}$ This does not confirm previous findings of its additive benefit as an augmentation strategy of CBT on phobic symptoms; ${ }^{66}$ thus, further studies are warranted. Potential new effective compounds may enhance fear extinction by stimulating the activity of medial prefrontal cortical areas (mPFC), such as methylene blue (MB), which may have an indirect action on $\mathrm{mPFC}$ by increasing brain cytochrome oxidase activity, improving oxidative energy metabolism, and thereby supplying the energy needs of synapses involved in consolidation of extinction memory. ${ }^{74}$ Clinical studies on the efficacy of MB for augmenting exposure-based treatments are currently underway.

The endocannabinoid system is another focus of research investigating new potential therapeutic approaches for anxiety disorders. Indeed, cannabinoid (CB) receptors have been linked to extinction learning in animal models, type $1 \mathrm{CB}$ (CB1) receptors have been found in brain areas related to anxiety and emotional learning (such as the amygdala and hippocampus), ${ }^{76}$ and $\mathrm{CB} 1$ antagonists lead to significant deficits in extinction learning, ${ }^{77}$ suggesting that $\mathrm{CB}$ receptor modulators may improve efficacy of exposure-based psychotherapies in phobic syndromes $;{ }^{78}$ however, data are not available on PD with AG. Cortisol has been also proposed as an augmentation strategy of extinction consolidation. Human and animal studies showed that acute increases of glucocorticoids can enhance emotional consolidation and extinction-based learning, ${ }^{79}$ the cortisol administration before virtual exposure to an acrophobic situation appeared to obtain a significantly greater fear reduction post treatment than placebo, ${ }^{80}$ and preliminary findings showed that the patients with $\mathrm{PD}$ and $\mathrm{AG}$ having least cortisol release during CBT exposures profited least from therapy. ${ }^{81}$ Finally, animal studies suggested that compounds with anticholinergic properties, acting in the primary sensory cortex, may improve sensory discrimination of the conditioned danger cue and its approximations; thus, a potential utility of these drugs on the fear-conditioned overgeneralization found in patients with PD has been proposed. ${ }^{15}$ Till now, no data have been available to evaluate the usefulness of these potential new compounds on AG and so future studies are needed.

\section{Conclusion}

Overall, there are several challenging issues in the pharmacological treatment of AG. First of all, a more stable and accepted psychopathological definition of $A G$ is crucial to improve the search for specific treatments. Further neurobiological, functional imaging, and clinical studies are warranted to better understand the pathogenesis of $A G$, either as a syndrome or as a distinct disorder, and, consequently, to better clarify the mechanisms of action and the usefulness of drugs. In PD with AG the clinical phenomena of phobic avoidance may not be simply related to spontaneous PAs; thus, potential specific effects of compounds on AG should be better tested, as well as new drugs that may have a specific efficacy, such as DCS. Finally, in clinical trials, patients with $\mathrm{PD}$ and $\mathrm{AG}$ are considered as a homogeneous group, without considering that different symptomatological profiles may exist, possibly reflecting multiple pathogenetic mechanisms involved in shaping agoraphobic behaviors. 


\begin{tabular}{|c|c|c|c|}
\hline Control group(s) & $\begin{array}{l}\text { Outcome measures for AG } \\
\text { and/or panic/anxiety }\end{array}$ & $\begin{array}{l}\text { Timing of } \\
\text { follow-up }\end{array}$ & Results \\
\hline Fluvoxamine (150 mg/day) & $\begin{array}{l}\text { FQ } \\
\text { Number of PAs (diary) } \\
\text { HAM-A }\end{array}$ & $\begin{array}{l}\text { Weeks } 3,4,5 \\
6,8,9\end{array}$ & $\begin{array}{l}\text { Similar improvement in both groups on all } \\
\text { measures, except for some superiority of } \\
\text { inositol in reducing PAs }\end{array}$ \\
\hline
\end{tabular}

Abbreviations: ACQ, Agoraphobic Cognition Questionnaire; ADS, Anxiety Discomfort Scale; AG, agoraphobia; BAI, Beck Anxiety Inventory; BDZ, benzodiazepine; CBT, cognitive behavioral therapy; CGI, Clinical Global Impression; CGI-I, Clinical Global Impression of Improvement; CGI-S, Clinical Global Impression of Severity; DCS, D-cycloserine; FQ, Fear Questionnaire; GPI, Global Patient's Impression scale; HAM-A, Hamilton Anxiety Rating Scale; MAOI, monoamine oxidase inhibitor; max, maximum; MI-A, Mobility Inventory for Agoraphobia; MI-PF, Mobility Inventory for Panic Frequency; NARI, selective noradrenergic reuptake inhibitor; ND, no data reported; P\&A, Panic and Agoraphobia Scale; PA, panic attack; PAAS, Panic and Anticipatory Anxiety Scale; PASS, Panic Attack Symptoms Scale; PD, panic disorder; PDSS, Panic Disorder Severity Scale; SNRI, serotonin-norepinephrine reuptake inhibitor; SPAAS, Sheehan Panic Attack and Anxiety Scale; SSRI, selective serotonin reuptake inhibitor; TCA, tricyclic antidepressant; vs, versus; WL, waiting list.

In conclusion, there are too many critical issues around both the clinical definition of AG and the pharmacological studies available to give a clear answer regarding the best drug choice for the treatment of AG. Much more research is needed before a specific psychopharmacology of AG can be discussed.

\section{Disclosure}

The authors report no conflicts of interest in this work.

\section{References}

1. Marks IM. The Agoraphobic Syndrome (Panic Disorder with Agoraphobia). In: Fears, Phobia and Ritual. New York: Oxford University Press; 1987:323-361.

2. American Psychiatric Association, ed. Diagnostic and Statistical Manual for Mental Disorders, Fourth Edition, Text Revision (DSM-IV-TR). Washington, DC: American Psychiatric Association; 2000.

3. World Health Organization. ICD-10, International Statistical Classification of Diseases and Related Health Problems. 10th ed. Arlington, VA: American Psychiatry Publishing; 1992.

4. Klein DF, Klein HM. The utility of the panic disorder concept. Eur Arch Psychiatry Neurol Sci. 1989;238(5-6):268-279.

5. Breier A, Charney DS, Heninger GR. Agoraphobia with panic attacks: development, diagnostic stability, and course of illness. Arch Gen Psychiatry. 1986;43(11):1029-1036.

6. Noyes R. The natural history of anxiety disorders. In Roth M, Noyes R Jr, Barrows GD, editors. Handbook of Anxiety: Biological, Clinical and Cultural Perspective. Vol 1. Amsterdam, The Netherlands: Elsevier Science Publishers; 1988:115-133.

7. Wittchen HU, Nocon A, Beesdo K, et al. Agoraphobia and panic: prospective-longitudinal relations suggest a rethinking of diagnostic concepts. Psychother Psychosom. 2008;77(3):147-157.

8. Fava GA, Rafanelli C, Tossani E, Grandi S. Agoraphobia is a disease: a tribute to Sir Martin Roth. Psychother Psychosom. 2008;77(3): $133-138$.

9. Faravelli C, Cosci F, Rotella F, Faravelli L, Catena Dell'osso M. Agoraphobia between panic and phobias: clinical epidemiology from the Sesto Fiorentino Study. Compr Psychiatry. 2008;49(3):283-287.

10. Perna G. Understanding anxiety disorders: from psychology to psychopathology of defense mechanisms from threat. Riv Psichiatr. 2011. In press.

11. Wittchen HU, Gloster AT, Beesdo-Baum K, Fava GA, Craske MG. Agoraphobia: a review of the diagnostic classificatory position and criteria. Depress Anxiety. 2010;27(2):113-133.

12. Perugi G, Frare F, Toni C. Diagnosis and treatment of agoraphobia with panic disorder. CNS Drugs. 2007;21(9):741-764.
13. Sugaya N, Kaiya H, Kumano H, Nomura S. Relationship between subtypes of irritable bowel syndrome and severity of symptoms associated with panic disorder. Scand J Gastroenterol. 2008;43(6):675-681.

14. Michael T, Blechert J, Vriends N, Margraf J, Wilhelm FH. Fear conditioning in panic disorder: enhanced resistance to extinction. J Abnorm Psychol. 2007;116(3):612-617.

15. Lissek S, Rabin S, Heller RE, et al. Overgeneralization of conditioned fear as a pathogenic marker of panic disorder. Am J Psychiatry. 2010; 167(1):47-55.

16. Lissek S, Rabin SJ, McDowell DJ, et al. Impaired discriminative fearconditioning resulting from elevated fear responding to learned safety cues among individuals with panic disorder. Behav Res Ther. 2009; 47(2):111-118.

17. Britton JC, Lissek S, Grillon C, Norcross MA, Pine DS. Development of anxiety: the role of threat appraisal and fear learning. Depress Anxiety. 2011;28(1):5-17.

18. McTeague LM, Lang PJ, Laplante MC, Bradley MM. Aversive imagery in panic disorder: agoraphobia severity, comorbidity, and defensive physiology. Biol Psychiatry. 2011;70(5):415-424.

19. Zanoveli JM, Ferreira-Netto C, Brandão ML. Conditioned place aversion organized in the dorsal periaqueductal gray recruits the laterodorsal nucleus of the thalamus and the basolateral amygdala. Exp Neurol. 2007; 208(1):127-136.

20. Wittmann A, Schlagenhauf F, John T, et al. A new paradigm (WestphalParadigm) to study the neural correlates of panic disorder with agoraphobia. Eur Arch Psychiatry Clin Neurosci. 2011;261(3):185-194.

21. Critchley HD. The human cortex responds to an interoceptive challenge. Proc Natl Acad Sci U S A. 2004;101(17):6333-6334.

22. Johnstone T, van Reekum CM, Urry HL, Kalin NH, Davidson RJ. Failure to regulate: counterproductive recruitment of top-down prefrontalsubcortical circuitry in major depression. $J$ Neurosci. 2007;27(33): 8877-8884.

23. Pasquini M, Berardelli I. Anxiety levels and related pharmacological drug treatment: a memorandum for the third millennium. Ann Ist Super Sanita. 2009;45(2):193-204.

24. Gorman JM, Kent JM, Sullivan GM, Coplan JD. Neuroanatomical hypothesis of panic disorder, revised. Am J Psychiatry. 2000;157(4): 493-505.

25. Myers KM, Davis M. Mechanisms of fear extinction. Mol Psychiatry. 2007;12(2):120-150.

26. Vervliet B. Learning and memory in conditioned fear extinction: effects of D-cycloserine. Acta Psychol (Amst). 2008;127(3):601-613.

27. Luft T, Pereira GS, Cammarota M, Izquierdo I. Different time course for the memory facilitating effect of bicuculline in hippocampus, entorhinal cortex, and posterior parietal cortex of rats. Neurobiol Learn Mem. 2004;82(1):52-56.

28. Perna G, Dario A, Caldirola D, Stefania B, Cesarani A, Bellodi L. Panic disorder: the role of the balance system. J Psychiatr Res. 2001;35(5): 279-286.

29. Staab JP. Chronic dizziness: the interface between psychiatry and neuro-otology. Curr Opin Neurol. 2006;19(1):41-48. 
30. Redfern MS, Furman JM, Jacob RG. Visually induced postural sway in anxiety disorders. J Anxiety Disord. 2007;21(5):704-716.

31. Caldirola D, Teggi R, Bondi S, et al. Is there a hypersensitive visual alarm system in panic disorder? Psychiatry Res. 2011;187(3):387-391.

32. Brandt T. Phobic postural vertigo. Neurology. 1996;46(6):1515-1519.

33. Löscher W. Abnormal circling behavior in rat mutants and its relevance to model specific brain dysfunctions. Neurosci Biobehav Rev. 2010; 34(1):31-49.

34. Lourenco SF, Longo MR, Pathman T. Near space and its relation to claustrophobic fear. Cognition. 2011;119(3):448-453.

35. Kellner M, Wiedemann K, Zihl J. Illumination perception in photophobic patients suffering from panic disorder with agoraphobia. Acta Psychiatr Scand. 1997;96(1):72-74.

36. Castrogiovanni P, Pieraccini F, Iapichino $\mathrm{S}$, et al. Electroretinogram B-wave amplitude in panic disorder. CNS Spectr. 2001;6(3):210-213.

37. Purdy RA. The role of the visual system in migraine: an update. Neurol Sci. 2011;32 Suppl 1:S89-S93.

38. Yamada K, Moriwaki K, Oiso H, Ishigooka J. High prevalence of comorbidity of migraine in outpatients with panic disorder and effectiveness of psychopharmacotherapy for both disorders: a retrospective open label study. Psychiatry Res. 2011;185(1-2):145-148.

39. Teggi R, Caldirola D, Colombo B, et al. Dizziness, migrainous vertigo and psychiatric disorders. J Laryngol Otol. 2010;124(3):285-290.

40. Van Apeldoorn FJ, Timmerman ME, Mersch PP, et al. A randomized trial of cognitive-behavioral therapy or selective serotonin reuptake inhibitor or both combined for panic disorder with or without agoraphobia: treatment results through 1-year follow-up. J Clin Psychiatry. 2010;71(5):574-586.

41. National Institute for Health and Clinical Excellence (NICE). Generalised anxiety disorder and panic disorder (with or without agoraphobia) in adults: management in primary, secondary and community care. NICE clinical guideline 113; Jan 2011. Available at: http:// www.nice.org.uk/nicemedia/live/13314/52599/52599.pdf. Accessed on September 15, 2011.

42. Van Apeldoorn FJ, van Hout WJ, Mersch PP, et al. Is a combined therapy more effective than either CBT or SSRI alone? Results of a multicenter trial on panic disorder with or without agoraphobia. Acta Psychiatr Scand. 2008;117(4):260-270.

43. Toni C, Perugi G, Frare F, Mata B, Akiskal HS. Spontaneous treatment discontinuation in panic disorder patients treated with antidepressants. Acta Psychiatr Scand. 2004;110(2):130-137.

44. Mavissakalian MR, Perel JM. 2nd year maintenance and discontinuation of imipramine in panic disorder with agoraphobia. Ann Clin Psychiatry. 2001;13(2):63-67.

45. Mavissakalian MR, Perel JM. Duration of imipramine therapy and relapse in panic disorder with agoraphobia. J Clin Psychopharmacol. 2002;22(3):294-299.

46. Marchand A, Coutu MF, Dupuis G, et al. Treatment of panic disorder with agoraphobia: randomized placebo-controlled trial of four psychosocial treatments combined with imipramine or placebo. Cogn Behav Ther. 2008;37(3):146-159.

47. Bandelow B, Broocks A, Pekrun G, et al. The use of the Panic and Agoraphobia Scale (P\&A) in a controlled clinical trial. Pharmacopsychiatry. 2000;33(5):174-181.

48. Perna G, Bertani A, Caldirola D, Gabriele A, Cocchi S, Bellodi L. Antipanic drug modulation of $35 \% \mathrm{CO}_{2}$ hyperreactivity and short-term treatment outcome. J Clin Psychopharmacol. 2002;22(3):300-308.

49. Uhlenhuth EH, Warner TD, Matuzas W. Interactive model of therapeutic response in panic disorder: moclobemide, a case in point. $J$ Clin Psychopharmacol. 2002;22(3):275-284.

50. Valença AM, Nardi AE, Nascimento I, Mezzasalma MA, Lopes FL, Zin W. Double-blind clonazepam vs placebo in panic disorder treatment. Arq Neuropsiquiatr. 2000;58(4):1025-1029.

51. Valença AM, Nardi AE, Mezzasalma MA, et al. Therapeutic response to benzodiazepine in panic disorder subtypes. Sao Paulo Med J. 2003; 121(2):77-80.
52. Katzelnick DJ, Saidi J, Vanelli MR, Jefferson JW, Harper JM, McCrary KE. Time to response in panic disorder in a naturalistic setting: combination therapy with alprazolam orally disintegrating tablets and serotonin reuptake inhibitors compared to serotonin reuptake inhibitors alone. Psychiatry (Edgmont). 2006;3(12):39-49.

53. Uhlenhuth EH, Matuzas W, Warner TD, Paine S, Lydiard RB, Pollack MH. Do antidepressants selectively suppress spontaneous (unexpected) panic attacks? A replication. J Clin Psychopharmacol. 2000;20(6):622-627.

54. Kampman M, Keijsers GP, Hoogduin CA, Hendriks GJ. A randomized, double-blind, placebo-controlled study of the effects of adjunctive paroxetine in panic disorder patients unsuccessfully treated with cognitivebehavioral therapy alone. J Clin Psychiatry. 2002;63(9):772-777.

55. Hendriks GJ, Keijsers GP, Kampman M, et al. A randomized controlled study of paroxetine and cognitive-behavioural therapy for late-life panic disorder. Acta Psychiatr Scand. 2010;122(1):11-19.

56. Wedekind D, Broocks A, Weiss N, Engel K, Neubert K, Bandelow B. A randomized, controlled trial of aerobic exercise in combination with paroxetine in the treatment of panic disorder. World J Biol Psychiatry. 2010;11(7):904-913.

57. Bandelow B, Behnke K, Lenoir S, et al. Sertraline versus paroxetine in the treatment of panic disorder: an acute, double-blind noninferiority comparison. J Clin Psychiatry. 2004;65(3):405-413.

58. Stahl SM, Gergel I, Li D. Escitalopram in the treatment of panic disorder: a randomized, double-blind, placebo-controlled trial. J Clin Psychiatry. 2003;64(11):1322-1327.

59. Bandelow B, Stein DJ, Dolberg OT, Andersen HF, Baldwin DS. Improvement of quality of life in panic disorder with escitalopram, citalopram, or placebo. Pharmacopsychiatry. 2007;40(4):152-156.

60. Perna G, Bertani A, Caldirola D, Smeraldi E, Bellodi L. A comparison of citalopram and paroxetine in the treatment of panic disorder: a randomized, single-blind study. Pharmacopsychiatry. 2001;34(3):85-90.

61. Versiani M, Cassano G, Perugi G, et al. Reboxetine, a selective norepinephrine reuptake inhibitor, is an effective and well-tolerated treatment for panic disorder. J Clin Psychiatry. 2002;63(1):31-37.

62. Bertani A, Perna G, Migliarese G, et al. Comparison of the treatment with paroxetine and reboxetine in panic disorder: a randomized, singleblind study. Pharmacopsychiatry. 2004;37(5):206-210.

63. Pollack MH, Lepola U, Koponen H, et al. A double-blind study of the efficacy of venlafaxine extended-release, paroxetine, and placebo in the treatment of panic disorder. Depress Anxiety. 2007;24(1):1-14.

64. Pande AC, Pollack MH, Crockatt J, et al. Placebo-controlled study of gabapentin treatment of panic disorder. J Clin Psychopharmacol. 2000;20(4):467-471.

65. Sandford JJ, Forshall S, Bell C, et al. Crossover trial of pagoclone and placebo in patients with DSM-IV panic disorder. J Psychopharmacol. 2001;15(3):205-208.

66. Otto MW, Tolin DF, Simon NM, et al. Efficacy of D-cycloserine for enhancing response to cognitive-behavior therapy for panic disorder. Biol Psychiatry. 2010;67(4):365-370.

67. Siegmund A, Golfels F, Finck C, et al. D-cycloserine does not improve but might slightly speed up the outcome of in-vivo exposure therapy in patients with severe agoraphobia and panic disorder in a randomized double blind clinical trial. J Psychiatr Res. 2011;45(8):1042-1047.

68. Palatnik A, Frolov K, Fux M, Benjamin J. Double-blind, controlled, crossover trial of inositol versus fluvoxamine for the treatment of panic disorder. J Clin Psychopharmacol. 2001;21(3):335-339.

69. Mitte K. A meta-analysis of the efficacy of psycho- and pharmacotherapy in panic disorder with and without agoraphobia. JAffect Disord. 2005;88(1):27-45.

70. Otto MW, Bruce SE, Deckersbach T. Benzodiazepine use, cognitive impairment, and cognitive-behavioral therapy for anxiety disorders: issues in the treatment of a patient in need. J Clin Psychiatry. 2005; 66 Supp1 2:34-38.

71. Levine J. Controlled trials of inositol in psychiatry. Eur Neuropsychopharmacol. 1997;7(2):147-155. 
72. Benjamin J, Levine J, Fux M, Aviv A, Levy D, Belmaker RH. Double-blind, placebo-controlled, crossover trial of inositol treatment for panic disorder. Am J Psychiatry. 1995;152(7):1084-1086.

73. Perna G, Alpini D, Caldirola D, Raponi G, Cesarani A, Bellodi L. Serotonergic modulation of the balance system in panic disorder: an open study. Depress Anxiety. 2003;17(2):101-106.

74. Kaplan GB, Moore KA. The use of cognitive enhancers in animal models of fear extinction. Pharmacol Biochem Behav. 2011;99(2):217-228.

75. Ressler KJ, Rothbaum BO, Tannenbaum L, et al. Cognitive enhancers as adjuncts to psychotherapy: use of D-cycloserine in phobic individuals to facilitate extinction of fear. Arch Gen Psychiatry. 2004;61(11): 1136-1144.

76. Moreira FA, Lutz B. The endocannabinoid system: emotion, learning and addiction. Addict Biol. 2008;13(2):196-212.

77. Hernandez G, Cheer JF. Extinction learning of rewards in the rat: is there a role for CB1 receptors? Psychopharmacology (Berl). 2011;217(2): 189-197.
78. Chhatwal JP, Davis M, Maguschak KA, Ressler KJ. Enhancing cannabinoid neurotransmission augments the extinction of conditioned fear. Neuropsychopharmacology. 2005;30(3):516-524.

79. Otto MW, McHugh RK, Kantak KM. Combined pharmacotherapy and cognitive-behavioral therapy for anxiety disorders: medication effects, glucocorticoids, and attenuated outcomes. Clin Psychol Sci Prac. 2010;17(2):91-103.

80. de Quervain DJ, Bentz D, Michael T, et al. Glucocorticoids enhance extinction-based psychotherapy. Proc Natl Acad Sci U S A. 2011; 108(16):6621-6625.

81. Siegmund A, Köster L, Meves AM, Plag J, Stoy M, Ströhle A. Stress hormones during flooding therapy and their relationship to therapy outcome in patients with panic disorder and agoraphobia. J Psychiatr Res. 2011;45(3):339-346.
Neuropsychiatric Disease and Treatment

\section{Publish your work in this journal}

Neuropsychiatric Disease and Treatment is an international, peerreviewed journal of clinical therapeutics and pharmacology focusing on concise rapid reporting of clinical or pre-clinical studies on a range of neuropsychiatric and neurological disorders. This journal is indexed on PubMed Central, the 'PsycINFO' database and CAS, and is the official

Submit your manuscript here: http://www.dovepress.com/neuropsychiatric-disease-and-treatment-journal

\section{Dovepress}

journal of The International Neuropsychiatric Association (INA). The manuscript management system is completely online and includes a very quick and fair peer-review system, which is all easy to use. Visit http://www.dovepress.com/testimonials.php to read real quotes from published authors. 